\title{
The Effect of Fiscal Rules on Public Investment if Budget Deficits Are Politically Motivated
}

\author{
Robert A.J. Dur *, Ben D. Peletier, and Otto H. Swank \\ Erasmus University Rotterdam, Tinbergen Institute, The Netherlands
}

November 1997

Keywords: fiscal rules; budget deficits; public investment.

JEL codes: D72, E62, H61, H62

\begin{abstract}
Uncertainty about the future preferences of the government may induce policy makers to run excessive budget deficits. As a solution to this problem, economists have proposed to impose a binding debt rule. In this paper we argue that a binding debt rule does not eliminate the distortions due to strategic behaviour of politicians. Rather, strategic manipulation shifts from public debt to public investment. As an alternative, we examine the effects of a capital borrowing rule which permits the government to run a budget deficit equal to the amount of public investment. We show that this rule effectively eliminates strategic behaviour.
\end{abstract}

\footnotetext{
* Corresponding author:

Robert A.J. Dur

EUR / Tinbergen Institute

P.O. Box 1738

3000 DR Rotterdam

The Netherlands

e-mail: dur@ few.eur.nl

fax \#: +31-10-4527347

phone \#: +31-10-4088923
} 


\section{Introduction}

Motivated by the dramatic rise in public debt in many OECD countries during the seventies and eighties, recent studies on political economy have dealt with the question why policy makers behave "fiscally irresponsible". The need for new explanations for the occurrence of budget deficits was enforced by a number of empirical studies which suggested that public debt accumulation cannot be fully attributed to traditional explanations, such as Keynesian motives and tax smoothing (Roubini and Sachs, 1989a, 1989b). Alesina and Perotti (1995) provide a comprehensive survey of recent politico economic theories of budget deficits. A general conclusion from these studies is that a bias towards public debt accumulation may exist due to distortions in the policy making process.

One strand in this literature focuses on the strategic role of public debt. The basic argument is that public debt can be used by the party in office in order to influence next period policy making. For instance, Tabellini and Alesina (1990) show that if the preferences of the next period government are uncertain, the current government has an incentive to accumulate debt. By running a deficit, the party in office is able to spend more on its preferred public goods at the expense of future public consumption, which may be determined by a policy maker with sharply different preferences. ${ }^{1}$

The tendency to run budget deficits for strategic purposes can be shown to yield socially sub-optimal outcomes. Electoral uncertainty induces the policy maker to deviate from perfectly smoothing resources over periods, and thus leads to lower welfare. If political parties could commit themselves to some level of the budget deficit, they would unanimously favour a binding debt rule, with allowed debt being equal to its socially optimal value (a special case is a balanced budget rule). Therefore, a natural conclusion from these studies is that a binding debt rule may be beneficial, since it prevents strategic use of public debt. ${ }^{2}$

${ }^{1}$ Related studies include Alesina and Tabellini (1990), Persson and Svensson (1989), and Lizzeri (1997). Some empirical evidence can be found in Alesina, Cohen, and Roubini (1992, 1993), Alesina, Roubini, and Cohen (1997), Grilli, Masciandaro, and Tabellini (1991), and Roubini and Sachs (1989a, 1989b) for OECD economies and in Edwards and Tabellini (1991) and Roubini (1991) for developing countries.

${ }^{2}$ Of course, a binding debt rule has serious drawbacks as it (1) excludes automatic stabilizers to work and (2) prevents governments to smooth distortionary taxes in response to unforeseen shocks. A more flexible rule, allowing budget deficits under a set of contingencies, could in principle be a solution, but raises serious monitoring problems. Hence, scholars have concluded 
In this paper, we argue that a binding debt rule does not eliminate the distortions due to strategic behaviour of politicians. Rather, a binding debt rule shifts strategic manipulation by politicians to other parts of public policy. The basic intuition is straightforward. After imposing a binding debt rule, policy makers can no longer use deficit financing strategically. ${ }^{3}$ However, the incentive to spend more resources now at the expense of future majorities' resources still exists. Hence, the party in office will start using other instruments with intertemporal effects, which are not binded by the rule.

Specifically, we investigate the effect of a binding debt rule on public investment. We present a model closely related to the model employed by Tabellini and Alesina (1990), in which uncertainty exists about the preferences of future governments with respect to public consumption. Besides public consumption and public debt, the policy maker in our model also decides on the level of public investment. Public investment decreases income available for consumption in the current period, but increases future income (one can think of spending on education, research and development, et cetera). Without a binding debt rule, public debt is used strategically while public investment is set socially optimal, even if the current party in office is sure to lose the elections. Thus, policy makers do not use public investment strategically if they can determine public debt freely. Under a binding debt rule, running deficits for strategic purposes is no longer possible. As a consequence, policy makers will use the other instrument of intertemporal nature: they will lower public investment in order to soften their budget constraint at the expense of future income. Hence, underinvestment will result from imposing a binding debt rule. ${ }^{4}$

In order to eliminate strategic behaviour completely, a more sophisticated fiscal rule is

that there is a trade-off between eliminating political distortions and socially optimal use of budget deficits (see e.g. Milesi-Ferretti, 1995, and Alesina and Perotti, 1996).

${ }^{3}$ Fiscal rules may, however, induce policy makers to use dubious accounting practices, thus rendering a debt rule non-binding (Milesi-Ferretti, 1997).

${ }^{4}$ The idea that policy makers can use public investment strategically is not new. Glazer (1989) argues that policy makers are biased towards durable projects relative to short-lived projects of the same type, because durable projects are more likely to remain under future policy makers, even if the latter have quite different preferences. Glazer's analysis thus deals with investment in durable public consumption goods. In the analysis below, we look at a different type of public investment. In our model, no direct utility is derived from public investment. Instead, public investment yields additional resources in future periods. 
needed. Obviously, adding a rule which forces policy makers to invest the socially optimal amount would be a solution. A possible candidate is an investment rule requiring policy makers to equalize benefits and costs of the last dollar investment. Such a rule, however, raises serious monitoring problems if there is some information asymmetry about the yield of public investment between the government and the opposition. We will argue that under this rule the government has an incentive to understate the yield of public investment, thus rendering the investment rule non-binding. The same reasoning applies to a rule under which maximum debt depends on the amount of public investment undertaken and the expected investment's yield. In principle, such a rule can eliminate strategic behaviour completely. However, under this rule the policy maker has an incentive to overstate the yield of public investment in order to be able to run higher deficits.

An alternative rule which overcomes this problem is a rule which permits policy makers to run a deficit equal to the amount of public investment they undertake. This capital borrowing rule, sometimes called the 'Golden Rule of government financing' (see e.g. Roubini, 1995), is currently in practice in most US states, but also in e.g. Dutch municipalities. We show that this capital borrowing rule effectively eliminates strategic behaviour. The intuition behind this result is clear. The capital borrowing rule requires that each dollar additional debt must be spent on public investment, whereas each dollar less investment must be accompanied by one dollar less debt creation. Hence, a policy maker can no longer increase current consumption at the expense of future consumption, neither by creating debt nor by lowering investment. Thus, strategic behaviour is effectively eliminated by the capital borrowing rule.

The capital borrowing rule thus really seems to be a 'Golden Rule'. Discretion may, however, still be preferred to the capital borrowing rule. As is the case with any binding fiscal rule, the capital borrowing rule excludes automatic stabilizers to work and prevents governments to smooth distortionary taxes in response to unforeseen shocks. A more flexible rule, allowing budget deficits under a set of contingencies, could in principle be a solution, but raises serious monitoring problems. Hence, a capital borrowing rule only increases total welfare if the costs associated with political distortions are high enough to compensate for welfare losses due to reduced flexibility of fiscal policy. Thus, such a rule seems particularly appropriate for countries with an unstable political system and a high degree of polarization between political parties.

Our analysis also points to the importance of the way public debt and public investment are 
defined in a capital borrowing rule. It is sometimes argued that public investment should be defined quite narrowly (Gramlich, 1995). The analysis in this paper strikes this policy prescription. If public debt or public investment are defined too narrowly, strategic behaviour will not be eliminated by the capital borrowing rule, but shifts to the non-binded part of public policy with intertemporal effects.

Besides contributing to the discussion on fiscal rules, this paper bears some positive implications. Firstly, we provide an explanation for the empirical regularity that public investment tends to be lowered far more strongly than public consumption under fiscal stringency (Roubini and Sachs, 1989b, De Haan, Sturm, and Sikken, 1996). Secondly, the analysis suggests that the level of public investment will be higher under a capital borrowing rule than under a binding debt rule. Exploiting the institutional variation across states within the US, Poterba (1995) provides some supportive evidence for this hypothesis.

In addition to the politico economic literature on fiscal deficits, the paper is related to the more general discussion between the Chicago and Virginia schools about the efficiency of constitutional restraints on policy makers. While the Virginia school argues that constitutional restraints increase total wealth by preventing governments to behave 'irresponsible', the Chicago view is that political restrictions decrease total wealth because these restrictions induce governments to use more costly methods. Recently, Lott (1997) has argued that this controversy boils down to an elasticity question: the total wealth effect depends on the degree to which more costly instruments are used in response to constitutional restraints. The analysis below is consistent with this argument.

The paper proceeds as follows. The next section presents the basic model. Next we derive in section 3 the level of public debt and public investment in the absence of electoral uncertainty. Section 4 shows that a deficit bias occurs if the policy maker is not certain to remain in office during both periods. The effect of a binding debt rule on public investment is examined in section 5. Alternative (more sophisticated) fiscal rules are the subject of section 6. Section 7 concludes.

\section{The basic model}

In this section we present a model closely related to Tabellini and Alesina (1990), in which the party in office decides on the level of taxes, the size of the budget deficit, and the size and composition of public spending. In order to keep the model tractable, we follow Tabellini and 
Alesina (1990) and confine the analysis to two periods. ${ }^{5}$ The party in office can transform private resources into two different public consumption goods ( $f$ and $g$ ) and into public investment $(i)$. Without affecting the results qualitatively, it is assumed that this transformation is costless, i.e. that taxes are nondistortionary. Besides raising taxes, the party in office can run a budget deficit $(b)$ in order to finance public expenditures. To concentrate on the main point of this paper, we assume that the economy's endowment, in the absence of public investment, is equal to 1 in both periods. ${ }^{6}$ The budget constraint in period 1 is thus given by:

$$
y_{1}=1+b-i-f_{1}-g_{1}
$$

where $y$ is after tax private income and subscripts denote time periods.

There are two ways in which the policy maker in period 1 affects the economy's resources in period 2. Firstly, debt created in the first period must be paid back in period 2. For reasons of simplicity we assume that the interest rate is zero and constant. Secondly, public investment undertaken in period 1 generates additional private resources in period 2 , described by the function $h(i)$, with $h^{\prime}(i)>0$ and $h^{\prime}{ }^{\prime}(i)<0$. For example, spending on education in period 1 leads to a rise in the productivity of workers, and thus to higher income in period 2 . The budget constraint in period 2 is thus given by:

$$
y_{2}=1-b+h(i)-f_{2}-g_{2}
$$

Each period, elections are held which determine the identity of the party in office. Two parties (denoted $\mathbf{j} \in\{\mathrm{d}, \mathrm{r}\}$ ) compete for office. Following Tabellini and Alesina (1990), the two

${ }^{5}$ In Alesina and Tabellini (1990) an infinite horizon model is shown to yield basically the same results as the two period model in Tabellini and Alesina (1990). We tried to incorporate decision making about public investment in an infinite horizon model, but the model eventually appeared to be intractable. An illustration of the intractability of the infinite horizon model is provided by Corsetti and Roubini (1997), who have to rely on simulations in order to obtain qualitative results from an open economy version of Alesina and Tabellini (1990).

${ }^{6}$ If the economy's resources differ between periods, a balanced budget is sub-optimal. See the literature on optimal taxation (Barro, 1979, and Lucas and Stokey, 1983). Recently, Corsetti and Roubini (1997) have shown that introducing shocks to the economy's resources does in no way affect the strategic use of public debt. 
parties are assumed to differ only in their preferences with respect to the public consumption goods. For example, party d cares more about welfare spending, while party $\mathrm{r}$ cares more about defence. To save on the number of first-order conditions below, we focus on the case of complete polarization, i.e. party d (r) cares about public consumption good $f(g)$ but not about good $g(f)$. The parties' utility functions are:

$$
\begin{aligned}
& U_{\mathrm{d}}=E\left\{\sum_{\mathrm{t}=1}^{2}\left[v\left(y_{\mathrm{t}}\right)+u\left(f_{\mathrm{t}}\right)\right]\right\} \\
& U_{\mathrm{r}}=E\left\{\sum_{\mathrm{t}=1}^{2}\left[v\left(y_{\mathrm{t}}\right)+u\left(g_{\mathrm{t}}\right)\right]\right\}
\end{aligned}
$$

where $E$ is an expectation operator, and the discount rate is assumed to be equal to one. The utility functions $v(\cdot)$ and $u(\cdot)$ are assumed to be concave, strictly increasing, twice continuously differentiable, and satisfy the conditions $v(0)=u(0)=0$ and $v^{\prime}(0), u^{\prime}(0) \rightarrow \infty$.

\section{Budget deficit and public investment in the absence of electoral uncertainty}

To isolate the effects of electoral uncertainty on public debt and public investment, let us start with examining the case in which there is no electoral uncertainty, i.e. the ruling party (say party d) is certain to stay in office in both periods. Given the assumption of complete polarization, party d will not supply public consumption good $g$. Substituting (1) and (2) into (3a), and maximizing with respect to $\mathrm{f}_{1}, \mathrm{f}_{2}, b$, and $i$ yield the following first-order conditions: 


$$
\begin{gathered}
-v^{\prime}\left(1+b-i-f_{1}\right)+u^{\prime}\left(f_{1}\right)=0 \\
-v^{\prime}\left(1-b+h(i)-f_{2}\right)+u^{\prime}\left(f_{2}\right)=0 \\
v^{\prime}\left(1+b-i-f_{1}\right)-v^{\prime}\left(1-b+h(i)-f_{2}\right)=0 \\
-v^{\prime}\left(1+b-i-f_{1}\right)+h^{\prime}(i) v^{\prime}\left(1-b+h(i)-f_{2}\right)=0
\end{gathered}
$$

Comparing (4.3) with the budget constraints (1) and (2), it is easy to see that the party in office perfectly smoothes after tax private income. Because public consumption is also perfectly smoothed by first-order conditions (4.1) and (4.2), the optimal budget deficit equals: $b^{*}=0.5(i$ $+h(i))>0$. Thus, costs $(i)$ and benefits $(h(i))$ of public investment are split equally over both periods by running a budget deficit. Finally, from (4.3) and (4.4) it follows that public investment must satisfy $h^{\prime}(i)=1$. Thus, the last dollar investment in period 1 yields one dollar additional income in period 2. Clearly, this level of public investment can be seen as socially optimal.

\section{Budget deficit and public investment with electoral uncertainty}

What happens with public debt and public investment if the party in office is not certain to remain in office? To answer this question, we assume that the party in office in period 1 faces an exogenously determined probability $\pi$ to remain in office $(0<\pi<1)$. The other party faces probability $(1-\pi)$ to win the elections at the beginning of period 2 . To ensure a time-consistent solution, we first determine the solution to the optimization problem faced by the party in office in period 2:

$$
\underset{\text { w.r.t. } c_{2} \in\left\{f_{2}, g_{2}\right\}}{\max \text { or }}=v\left(1-b+h(i)-c_{2}\right)+u\left(c_{2}\right)
$$

where public consumption, denoted $c_{2}$, can be either of type $f_{2}$ or $g_{2}$, depending on the 
identity of the party in office in period 2. Solving (5) yields the first-order condition:

$$
-v^{\prime}\left(1-b+h(i)-c_{2}\right)+u^{\prime}\left(c_{2}\right)=0
$$

Obviously, both parties choose the same amount of public consumption in period 2 if in office $\left(\mathrm{f}_{2}=\mathrm{g}_{2}\right)$. Condition (6) implicitly defines $f_{2}$ and $g_{2}$ as a function of $b$ and $i$. Applying the implicit function theorem, we obtain:

$$
\begin{aligned}
& \frac{\mathrm{d} c_{2}}{\mathrm{~d} b}=\frac{-v^{\prime \prime}}{v^{\prime \prime}+u^{\prime \prime}} \in(-1,0) \\
& \frac{\mathrm{d} c_{2}}{\mathrm{~d} i}=h^{\prime}(i) \frac{v^{\prime \prime}}{v^{\prime \prime}+u^{\prime \prime}}>0
\end{aligned}
$$

Hence, public consumption in period 2 depends negatively on the debt inherited from period 1 , and positively on public investment made in period 1 . Note that the effects of deficits and investment on period 2 public consumption are closely related: the effect of less investment is equal to $h^{\prime}(i)$ times the effect of higher debt. Intuitively, one dollar of additional debt constrains the period 2 government by one extra dollar, whereas one dollar less public investment leaves the period 2 government with $h^{\prime}(i)$ less taxable income.

When deciding on the size and composition of public spending in period 1 , the party in office in the first period (say party d) takes into account the effects of its decisions on next period's budget constraint. Party d faces the following maximization problem at the beginning of period 1:

$$
\begin{gathered}
\max _{\text {w.r.t. } f_{1}, b, i} U_{\mathrm{d}}=v\left(1+b-i-f_{1}\right)+u\left(f_{1}\right)+\pi\left[v\left(1-b+h(i)-f_{2}\right)+u\left(f_{2}\right)\right]+ \\
+(1-\pi)\left[v\left(1-b+h(i)-g_{2}\right)\right]
\end{gathered}
$$

yielding the following first-order conditions: 


$$
\begin{gathered}
-v^{\prime}\left(1+b-i-f_{1}\right)+u^{\prime}\left(f_{1}\right)=0 \\
v^{\prime}\left(1+b-i-f_{1}\right)-\left[1+(1-\pi) \frac{\mathrm{d} g_{2}}{\mathrm{~d} b}\right] v^{\prime}\left(1-b+h(i)-f_{2}\right)=0 \\
-v^{\prime}\left(1+b-i-f_{1}\right)+\left[h^{\prime}(i)-(1-\pi) \frac{\mathrm{d} g_{2}}{\mathrm{~d} i}\right] v^{\prime}\left(1-b+h(i)-f_{2}\right)=0
\end{gathered}
$$

which have been simplified using equation (6). ${ }^{7}$ Comparing these first-order conditions with (4.1)-(4.4), it is easy to see how electoral uncertainty affects spending decisions in the first period. When certain to remain in office next period, after tax private income and public consumption are perfectly smoothed. Under uncertainty, perfectly smoothing is not an optimal choice because part of the resources left to the next government may not be spent useful from the current government's point of view. Hence, it is beneficial to increase after tax private income and public consumption in period 1 at the expense of public consumption in period 2, because the latter might be of type $g$. Thus, while deciding on the level of public investment, the party in office takes into account that with probability $(1-\pi)$ a part of the investment's yield $\left(\frac{\mathrm{d} g_{2}}{\mathrm{~d} i}\right)$ is spent on public consumption good $g$, from which it derives no utility. Analogously, part of the debt created in the first period $\left(\frac{\mathrm{d} g_{2}}{\mathrm{~d} b}\right)$ is paid back in the second period by cutting public consumption, which is useless in the eyes of the current government with probability $(1-\pi)$.

To solve the model, we combine (9.2) and (9.3), which leads to the result that in the optimum $h^{\prime}(i)=1$. Hence, electoral uncertainty does not affect public investment. Intuitively, the party in office wants to smooth income to a lesser extent than above. It has two instruments to smooth income: public investment and debt. The instruments are equally costly in terms of available resources in period 2 if and only if $h^{\prime}(i)=1$; then one dollar less investment has exactly the same effect on the next period's budget constraint as one dollar of

${ }^{7}$ Concavity of $v(\cdot)$ does not guarentee that the second-order conditions are satisfied. Therefore, an additional (weak) assumption with respect to $\mathrm{v}^{\prime \prime \prime}(\cdot)$ has to be made. 
additional debt. A lower level of public investment softens the period 1 government budget constraint equally, but tightens the next period government's budget constraint more strongly than leaving higher debt, thus leading to less after tax private income in period 2. So, although the current government realizes that part of the investment's yield may be spent on good $g$, it does not lower public investment because a less expensive instrument is available to spend future resources in the current period. Using the result that $h^{\prime}(i)=1$, combining equations (6), (9.1) and (9.2) yields $f_{1}>f_{2}\left(=g_{2}\right)$. Finally by using equation (9.1), we find that public debt is equal to $b^{* *}>0.5(i+h(i))+0.5\left(f_{1}-f_{2}\right)$, which is higher than public debt in the absence of electoral uncertainty (recall $b^{*}=0.5(i+h(i))$. Hence, electoral uncertainty induces the party in office to run a higher budget deficit for strategic reasons. This result is in line with Tabellini and Alesina (1990), who consider a model without public investment. Thus, the argument by Tabellini and Alesina (1990) is quite robust.

\section{Public investment under a binding debt rule}

The analysis in the previous section suggests that uncertainty about election outcomes leads to higher than optimal budget deficits. A policy maker who is uncertain about his reelection will use deficit financing not only to smooth costs and benefits of public investment, but also to soften his own budget constraint at the expense of the budget available to future policy makers. Because the policy maker deviates from perfectly smoothing resources over periods, electoral uncertainty leads to lower welfare. Therefore, a natural conclusion seems to be that a binding rule which brings the deficit closer to its optimal level is welfare-improving. Indeed, Tabellini and Alesina (1990) show that if voters can commit to a deficit level before it is known which party is in office in period 1, they unanimously favour a binding debt rule, with allowed debt being equal to its socially optimal level (a special case being a balanced budget rule). This result is, however, obtained in a model with only one intertemporal policy instrument to the policy maker's disposal. In this section we examine the effect of imposing a binding debt rule on the use of other policy instruments with intertemporal effects, in particular public investment.

For a debt rule to be binding, maximum debt must be lower than debt under discretion $\left(b^{* *}\right)$, i.e. $b^{\max }<b^{* *}>0.5\left(i^{* *}+h\left(i^{* *}\right)\right)+0.5\left(f_{1}^{* *}-f_{2}^{* *}\right)$. Clearly, if the permitted level of debt $\left(b^{\max }\right)$ is lower than optimal public debt in the absence of strategic behaviour $\left(b^{*}\right.$, 
derived in section 2), a binding debt rule leads to inferior outcomes since not only the strategic use, but also the efficient use of public debt is hindered. Therefore, we examine the case of a binding debt rule with $b^{*} \leq b^{\max }<b^{* *}$. Under this rule, the party in office (say party d) faces the following optimization problem:

$$
\begin{gathered}
\max _{\text {w.r.t. } f_{1}, i} U=v\left(1+b^{\max }-i-f_{1}\right)+u\left(f_{1}\right)+\pi\left[v\left(1-b^{\max }+h(i)-f_{2}\right)+u\left(f_{2}\right)\right]+ \\
+(1-\pi)\left[v\left(1-b^{\max }+h(i)-g_{2}\right)\right]
\end{gathered}
$$

The solution of the optimization problem of the party in office in period 2 is again described by equation (6), with $b$ of course equal to $b^{\max }$. Analogously, the first-order conditions associated with the optimization problem defined in (10) are simply (9.1) and (9.3) above with $b=b^{\max }$. Substituting conditions (6) and (9.1) into (9.3) we obtain:

$$
u^{\prime}\left(f_{1}\right)=h^{\prime}(i)\left[1-(1-\pi) \frac{v^{\prime \prime}}{v^{\prime \prime}+u^{\prime \prime}}\right] u^{\prime}\left(f_{2}\right)
$$

PROPOSITION: The first-order conditions associated with the optimization problem (10) imply that $h^{\prime}(i)>1$ if $0<\pi<1$.

\section{PROOF:}

If reelection is uncertain $(0<\pi<1)$, then $0<\left[1-(1-\pi) \frac{v^{\prime \prime}}{v^{\prime \prime}+u^{\prime \prime}}\right]<1$. Therefore, if $h^{\prime}(i) \leq 1$ is the optimal solution, then it follows from (11) that $f_{2}<f_{1}$. From (6) and (9.1) we know that if $f_{2}<f_{1}$, then it must hold that $1+b^{\max }-i-f_{1}>1-b^{\max }+h(i)-f_{2}$. However, this yields a contradiction with the definition of a binding debt rule, namely that: $b^{\max }<b^{* *}>0.5\left(i^{* *}+h\left(i^{* *}\right)\right)+0.5\left(f_{1}^{* *}-f_{2}^{* *}\right)$. Hence, $h^{\prime}(i) \leq 1$ can be excluded as the optimum. Only if $h^{\prime}(i)$ is sufficiently larger than 1 , the first-order conditions are satisfied.

The above proposition states that a binding debt rule leads to underinvestment if the preferences of the next government are uncertain. Because part of the investment's yield may (with probability $(1-\pi)$ ) be spent on public goods which are useless to the current party in 
office (public consumption of type $g$ ), the party in office cares less about the budget constraint faced by next period's government. Without a maximum debt rule, the period 1 government chooses the least costly instrument to soften its own budget constraint at the expense of next period resources. If the deficit instrument is restricted by a debt rule, the party in office uses public investment to constrain its successor with possibly different preferences. Hence, imposing a binding debt rule does not eliminate the distortions resulting from strategic behaviour of the policy maker, but shifts strategic manipulation to public investment.

\section{Public investment and budget deficits under alternative fiscal rules}

The results derived in the previous section suggest that a debt rule may not be a good solution to the problem of excessive debt accumulation due to political distortions. Although socially undesirable budget deficits are effectively eliminated, underinvestment results as policy makers seek alternative instruments to soften their own budget constraint at the expense of the future policy maker's budget. Analogous to the deficit problem, the problem of underinvestment can potentially be solved by imposing an additional binding rule on the political actors. This rule should force policy makers to invest the socially optimal amount $i^{*}$ derived in section 2 . A possible candidate is an investment rule requiring policy makers to equalize benefits and costs of the last dollar investment (thus, this rule would require that the maximum value of $h^{\prime}(i)=1$ ).

Alternatively, one might think of a more sophisticated debt rule leading to both optimal investment and optimal public debt. In the above model, this sophisticated debt rule could be $b$ $\leq 0.5(i+h(i))$. Thus, under this rule the amount of debt a policy maker may leave to its successor directly depends on the amount of public investment undertaken by the policy maker. Strategic debt accumulation is prevented by this sophisticated debt rule, because policy makers are forced to use debt financing only to spread costs and benefits of public investment. In addition, this rule prevents underinvestment because the first period policy maker's resources increase with public investment up to the point where $h^{\prime}(i)=1$, the socially optimal amount of public investment. Hence, strategic behaviour is effectively eliminated under this sophisticated debt rule.

Notwithstanding their theoretical appeal, both the investment rule and the sophisticated debt rule have severe practical problems. Since they both depend on the investment's yield in the second period (the function $h(i)$ ), monitoring problems emerge if there is some information asymmetry about the investment's yield between the government and the opposition. For 
example, under a binding debt rule combined with an investment rule requiring that $h^{\prime}(i)=1$, the policy maker will have an incentive to understate the investment's yield. By stating that $h^{\prime}(i)=1$ is reached at a lower level of $i$ than $i^{*}$, the policy maker can spend less on public investment, thus raising his utility at the margin (recall from the previous section that $h^{\prime}(i)>1$ is optimal under a binding debt rule). Under the sophisticated debt rule $(b \leq 0.5(i+h(i)))$, the policy maker will overstate the investment's yield. By stating that the total yield of actual spending on public investment $(h(i))$ is higher than actual (while giving true information about the value of $\left.h^{\prime}(i)\right)$, the policy maker is permitted to create higher public debt while keeping public investment at its socially optimal value. Indeed, by lying about the value of $h(i)$, the policy maker is able to reach the discretionary state with $b=b^{* *}$ and $h^{\prime}(i)=1$.

As an alternative, we might think of a capital borrowing rule which permits each policy maker to run a budget deficit equal to the amount of public investment undertaken by the policy maker $(b \leq i)$. Such a rule (sometimes called the 'Golden Rule of government financing') is currently in practice in most states in the US but also in e.g. Dutch municipalities. As with the sophisticated debt rule, the allowed amounts of debt creation and public investment are directly linked. The capital borrowing rule overcomes the monitoring problem associated with the sophisticated debt rule, because the allowed budget deficit is independent on the public investment's yield.

To analyze the consequences of a capital borrowing rule on public debt and public investment, we use the model set out above. The optimization problem the party in office faces in period 2 is equal to (5) in section 2 with the exception that we replace $b$ with $i$ (it is easy to show that the $b \leq i$ rule is a binding constraint). The direct plus indirect (via higher public debt) effect of public investment on public consumption in period 2 is now equal to:

$$
\frac{\mathrm{d} c_{2}}{\mathrm{~d} i}=\left(h^{\prime}(i)-1\right) \frac{v^{\prime \prime}}{v^{\prime \prime}+u^{\prime \prime}}
$$

Hence, public consumption in period 2 now decreases with public investment for high values of investment $\left(h^{\prime}(i)<1\right)$ due to the accompanying rise in public debt. The optimization problem the party in office faces in the first period (say party d) is: 


$$
\begin{gathered}
\max _{\text {w.r.t. } f_{1}, i} U_{\mathrm{d}}=v\left(1-f_{1}\right)+u\left(f_{1}\right)+\pi\left[v\left(1-i+h(i)-f_{2}\right)+u\left(f_{2}\right)\right]+ \\
+(1-\pi)\left[v\left(1-i+h(i)-g_{2}\right)\right]
\end{gathered}
$$

Note that under the capital borrowing rule, neither public investment nor the budget deficit affects public consumption or after tax private income in period 1. Each dollar of additional debt must be spent on investment and each dollar less investment must be accompanied by one dollar less debt creation. Hence, under the capital borrowing rule the party in office is unable to soften its own budget constraint either by means of creating debt or by lowering public investment. The first-order conditions associated with (13) are:

$$
\begin{gathered}
-v^{\prime}\left(1-f_{1}\right)+u^{\prime}\left(f_{1}\right)=0 \\
{\left[h^{\prime}(i)-1-(1-\pi) \frac{\mathrm{d} g_{2}}{\mathrm{~d} i}\right] v^{\prime}\left(1-b+h(i)-f_{2}\right)=0}
\end{gathered}
$$

which have been simplified using (6). Using (12), it is straightforward to derive that in the optimum $h^{\prime}(i)=1$. Hence, under the capital borrowing rule, the amount of public investment is set equal to its socially optimal level $(i *)$. The intuition is clear. Since the period 1 government cannot soften its own budget constraint using budget deficits or public investment, it has no incentive to invest less than is socially optimal.

The capital borrowing rule thus really seems to be a 'Golden Rule' as it eliminates distortions resulting from strategic behaviour. Discretion may, however, still be preferred to the capital borrowing rule. A well-known reason is that this rule, like any binding fiscal rule, excludes automatic stabilizers to work and prevents governments to smooth distortionary taxes 
in response to unforeseen shocks. ${ }^{8}$ Hence, a capital borrowing rule only increases total welfare if the costs associated with political distortions are high enough to compensate for welfare losses due to reduced flexibility of fiscal policy. Thus, such a rule is most appropriate for countries with an unstable political system and a high degree of polarization between political parties.

Our analysis also points to the importance of the way public debt and public investment are defined in a capital borrowing rule. It is sometimes argued that public investment should be defined quite narrowly (Gramlich, 1995). The analysis in this paper strikes this policy prescription. If public debt or public investment are defined too narrowly, strategic behaviour will not be eliminated by the capital borrowing rule, but shifts to the non-binded part of public policy with intertemporal effects. This can easily be shown by extending the model above with an additional type of public investment (e.g. $m$ ). Imposing a debt rule reduces both $i$ and $m$ due to strategic behaviour. Imposing a capital borrowing rule $b \leq i$ reduces $m$ even further.

\section{Conclusions}

It is well-known that uncertainty about the future preferences of the government may bring public debt on a sub-optimal path. As a solution to this problem, economists have proposed to impose a binding debt rule. In this paper we have shown that a binding debt rule shifts strategic manipulation of public debt to strategic manipulation of public investment. Under a binding debt rule, electoral uncertainty about the future preferences of the government leads to underinvestment.

As an alternative, we have examined the effects of a capital borrowing rule. Under a capital borrowing rule, the government is permitted to run a budget deficit equal to the amount of public investment. We have shown that under this rule strategic behaviour is effectively eliminated. Moreover, we have argued that public investment should not be defined too narrowly. If public debt or public investment are defined too narrowly, strategic behaviour will

\footnotetext{
${ }^{8}$ Moreover, even in the absence of shocks, the model suggests that public debt is too low under a capital borrowing rule since optimal debt $b^{*}=0.5\left(i^{*}+h\left(i^{*}\right)\right)>i^{*}$. Clearly, this result depends heavily on the simple structure of the model, especially the short time horizon. In an infinite horizon model, with public investment taking place in all periods, this problem is of less concern since in each period there is a yield from public investment undertaken in the previous period.
} 
not be eliminated by the capital borrowing rule, but shifts to the non-binded part of public policy with intertemporal effects.

\section{References}

Alesina, A., G.D. Cohen, and N. Roubini (1992), Macroeconomic Policy and Elections in OECD Democracies, Economics and Politics, 4, p. 1-30.

Alesina, A., G.D. Cohen, and N. Roubini (1993), Electoral Business Cycle in Industrial Democracies, European Journal of Political Economy, 9, p. 1-23.

Alesina, A., and R. Perotti (1995), The Political Economy of Budget Deficits, IMF Staff Papers, 42, p. 1-31.

Alesina, A., and R. Perotti (1996), Fiscal Discipline and the Budget Process, American Economic Review (Papers and Proceedings), 86, p. 401-407.

Alesina, A., N. Roubini, and G. Cohen (1997), Political Cycles and the Macroeconomy, forthcoming, Cambridge: MIT Press.

Alesina, A., and G. Tabellini (1990), A Positive Theory of Fiscal Deficits and Government Debt, Review of Economic Studies, 57, p. 403-414.

Barro, R.J. (1979), On the Determination of the Public Debt, Journal of Political Economy, 87, p. 940-71.

Corsetti, G., and N. Roubini (1997), Politically Motivated Fiscal Deficits: Policy Issues in Closed and Open Economies, Economics and Politics, 9, p. 27-54.

Edwards, S., and G. Tabellini (1991), Explaining Fiscal Policies and Inflation in Developing Countries, Journal of International Money and Finance, 10, Supplement, p. S16-S48. 
Glazer, A. (1989), Politics and the Choice of Durability, American Economic Review, 79, p. 1207-1213.

Gramlich, E.M. (1995), The Politics and Economics of Budget Deficit Control: Policy Questions and Research Questions, in: J.S. Banks and E.A. Hanushek (eds.), Modern political economy : old topics, new directions, p. 171-190, Cambridge: Cambridge University Press.

Grilli, V., D. Masciandaro, and G. Tabellini (1991), Political and Monetary Institutions and Public Financial Policies in the Industrial Countries, Economic Policy, 13, p. 341-392.

Haan, J. de, J.E. Sturm, and B.J. Sikken (1996), Government Capital Formation: Explaining the Decline, Weltwirtschaftliches Archiv - Review of World Economics, 132, p. 55-74.

Lizzeri, A. (1997), Budget Deficits and Redistributive Politics, Mimeo, Princeton University.

Lott, J.R., Jr. (1997), Does Political Reform Increase Wealth?: or, Why the Difference between the Chicago and Virginia Schools Is Really an Elasticity Question, Public Choice, 91, p. 219-227.

Lucas, R.E., Jr., and N. Stokey (1983), Optimal Fiscal and Monetary Policy in an Economy without Capital, Journal of Monetary Economics, 12, p. 55-93.

Milesi-Ferretti, G.M. (1997), Fiscal Rules and the Budget Process, CEPR discussion paper 1664.

Milesi-Ferretti, G.M. (1997), Good, Bad or Ugly? On the Effects of Fiscal Rules with Creative Accounting, Mimeo, IMF Research Department.

Persson, T., and L.E.O. Svensson (1989), Why a Stubborn Conservative Would Run a Deficit: Policy with Time-Inconsistent Preferences, Quarterly Journal of Economics, 104, p. 325-345. 
Poterba, J.M. (1995), Capital Budgets, Borrowing Rules, and State Capital Spending, Journal of Public Economics, 56, p. 165-187.

Roubini, N. (1991), Economic and Political Determinants of Budget Deficits in Developing Countries, Journal of International Money and Finance, 10, Supplement, p. S49-S72.

Roubini, N. (1995), The Economics of Fiscal Bondage: The Balanced Budget Amendment and Other Binding Fiscal Rules, Mimeo, New York University.

Roubini, N., and J.D. Sachs (1989a), Political and Economic Determinants of Budget Deficits in the Industrial Democracies, European Economic Review, 33, p. 903-933.

Roubini, N., and J. Sachs (1989b), Government Spending and Budget Deficits in the Industrial Countries, Economic Policy, 8, p. 99-132.

Tabellini, G., and A. Alesina (1990), Voting on the Budget Deficit, American Economic Review, 80, p. 37-49. 